\title{
Dry residue of cassava as a supplementation in broiler feed with or without addition of carbohydrases
}

\author{
Resíduo seco de fecularia na alimentação de frangos de corte \\ suplementados ou não com carboidrases
}

\author{
Jomara Broch $^{1 *}$; Ricardo Vianna Nunes ${ }^{2}$; Vladimir de Oliveira ${ }^{3}$; Idiana Mara da \\ Silva ${ }^{4}$; Cleison de Souza ${ }^{1}$; Lucas Wachholz ${ }^{1}$
}

\begin{abstract}
The objective of this study was to evaluate the inclusion of dry residue of cassava (DRC) with or without supplementation of carbohydrases on performance, carcass yield, cuts and organs, blood parameters and meat quality of broiler chickens. Birds were distributed in a completely randomised design in a $2 \times 5$ factorial scheme, with or without addition of carbohydrases and five levels of DRC inclusion, resulting in 10 treatments with 5 replicates of 22 birds each. At 21 days of age, two birds of each treatment were fasted for 6 hours for blood brachial puncture. At 42 days, four birds per pen were slaughtered to determine carcass yield, cuts, organs, percentage of abdominal fat and meat quality. Between 1-21 days of age, there was an interaction $(\mathrm{P}<0.05)$ between carbohydrase and DRC supplementation on weight gain (WG) and feed intake, which showed a decreasing linear effect without the inclusion of carbohydrases. In the period from 1 to 42 days, there was an interaction $(\mathrm{P}<0.05)$ between carbohydrase supplementation and DRC inclusion on the variables WG and feed conversion. Carbohydrase inclusion provided an increase $(\mathrm{P}<0.05)$ in the concentrations of cholesterol, triglycerides, creatinine, gamma GT and blood glucose. Concentrations of gamma GT were increased and levels of alanine aminotransferase and creatinine were decreased $(\mathrm{P}<0.05)$ with DRC inclusion. At 24 hours post mortem, there was a significant interaction $(\mathrm{P}<0.05)$ for breast meat between carbohydrase supplementation and DRC inclusion for the variable L. The analysed values of $\mathrm{pH}$, water holding capacity and shear force of the breast meat were not affected $(\mathrm{P}>0.05)$ by DRC inclusion and carbohydrase addition. However, cooking loss was influenced $(\mathrm{P}<0.05)$ by levels of inclusion of DRC. The $\mathrm{L}$ and $\mathrm{a}^{*}$ variable and the feet of broiler chickens were not affected $(\mathrm{P}>0.05)$ by DRC levels and carbohydrase addition. The colour variable $\mathrm{b}^{*}$ showed a decrease $(\mathrm{P}<0.05)$ from $5 \%$ level of inclusion. The results of this study show that DRC can be used in the diets of broiler chickens from 1 to 21 days old to the assessed level of $10 \%$, provided that carbohydrase is added.
\end{abstract}

Key words: Broilers. Enzyme complex. Cassava. Nutrition.

1 Discentes, Curso de Doutorado do Programa de Pós-Graduação em Zootecnia, Universidade Estadual do Oeste do Paraná, UNIOESTE, Marechal Cândido Rondon, PR, Brasil. E-mail: brochjomara@yahoo.com.br; cleisondsz@hotmail.com; lucaswach@hotmail.com

2 Prof. Dr., Programa de Pós-Graduação em Zootecnia, UNIOESTE, Marechal Cândido Rondon, PR, Brasil. E-mail: nunesrv@, hotmail.com

3 Prof. Dr., Programa de Pós-Graduação em Zootecnia, Universidade Federal de Santa Maria, UFSM, Santa Maria, RS, Brasil. E-mail: vladimir.oliveira@ufsm.br

4 Discentes, Curso de Mestrado do Programa de Pós-Graduação em Zootecnia, UNIOESTE, Marechal Cândido Rondon, PR, Brasil. E-mail: idianams@outlook.com

* Author for correspondence

Received: Sept. 26, 2016 Approved: Jan. 23, 2017 


\section{Resumo}

O objetivo do trabalho foi avaliar a inclusão do resíduo seco de fecularia(RSF) com ou sem a suplementação de carboidrases sobre o desempenho, o rendimento de carcaça, cortes e órgãos, parâmetros sanguíneos e qualidade da carne de frangos de corte. As aves foram distribuídas em um delineamento inteiramente casualizado, em esquema fatorial $2 \times 5$, constituído da combinação da adição ou não de carboidrases e cinco níveis de inclusão de RSF, resultando em 10 tratamentos, com cinco repetições de 22 aves cada. Aos 21 dias de idade, duas aves por unidade experimental foram mantidas em jejum por 6 horas, para coleta de sangue via punção braquial. Aos 42 dias de idade, quatro aves por unidade experimental foram abatidas para determinação do rendimento de carcaça, cortes, órgãos, porcentagem de gordura abdominal e avaliação da qualidade da carne. No período de 1 a 21 dias de idade houve interação ( $\mathrm{P}$ $<0,05)$ entre a suplementação de carboidrases e o RSF para ganho de peso e consumo de ração, que apresentaram comportamento linear decrescente sem a inclusão de carboidrases. No período de 1 a 42 dias houve interação $(\mathrm{P}<0,05)$ entre a suplementação de carboidrases e a inclusão do RSF para as variáveis GP e conversão alimentar. A inclusão das carboidrases proporcionou um aumento $(\mathrm{P}<0,05)$ na concentração de colesterol, triglicerídeos, creatinina, gama GT e glicose no sangue. A concentração da Gama GT apresentou um acréscimo e da alanina aminotransferase e creatinina apresentaram um decréscimo $(\mathrm{P}<0,05)$ com a inclusão do RSF. Na análise 24 horas post mortem da carne do peito houve interação significativa $(\mathrm{P}<0,05)$ entre a suplementação de carboidrases e a inclusão do RSF para a variável L. Os valores analisados de $\mathrm{pH}$, capacidade de retenção de água e força de cisalhamento da carne do peito não foram influenciados $(\mathrm{P}>0,05)$ pela inclusão do RSF e adição ou não de carboidrases. A perda por cocção foi influenciada $(\mathrm{P}<0,05)$ pelos níveis de inclusão do RSF. As variáveis L e a* dos pés dos frangos de corte não foram influenciadas $(\mathrm{P}>0,05)$ pelos níveis do RSF e adição ou não de carboidrases. A variável de cor $\mathrm{b}^{*}$ apresentou um decréscimo $(\mathrm{P}<0,05)$ a partir do nível de $5 \%$ de inclusão. O RSF pode ser utilizado nas dietas de frangos de corte de 1 a 21 dias de idade até o nível avaliado de $10 \%$, desde que associado ao uso de carboidrases.

Palavras-chave: Aves. Complexo enzimático. Mandioca. Nutrição.

\section{Introduction}

The use of co-products in agricultural production system has made it possible to reduce feed costs with in animal production. Dry starch residue is a coproduct of cassava processing and characterised by large amounts of fibre which cannot be extracted during processing (RAUPP et al., 1999).

Because cassava is produced in great quantities and has high nutritional qualities, it has great potential to partially replace corn in broiler diet. According to studies on the evaluation of nutritional and energy values, DRC contains $3,519 \mathrm{kcal} \mathrm{kg}^{-1}$ of crude energy, $0.98 \%$ of protein, $27.0 \%$ of neutral detergent fiber and $19.5 \%$ acid detergent fibre.

Picoli et al. (2014) emphasise the relevance of the high content of non-starch polysaccharides (NSP) and lignin in DRC, similar to Silva and
Cabello (2010), who also stress the importance of using such co-products because of their low pigment capacity, high soluble and insoluble fibre content and the presence of NSP.

Non-starch polysaccharides are the main constituents of plant cell walls and cannot be digested by birds, because their binding is resistant to hydrolysis in the digestive tract. The indigestibility of these components can reduce the energy of the food and negatively interfere with the use of other nutrients, impeding animal performance (CONTE et al., 2003).

The use of carbohydrases such as amylase, glucanase and xylanase in poultry diets has been prominent over the last few years. Its benefits are related to the hydrolysis of the food components, improving the digesta use and starch degradation 
and reducing the viscosity of the diets, contributing to the use of energy and, consequently, improving the zootechnical production parameters (YU; CHUNG, 2004).

In this context, it is believed that carbohydrase supplementation in diets containing DRC can promote a better productive efficiency of the birds by improving the digestion of low quality components, such as NSP, or even by increasing the availability of other nutrients (TORRES et al., 2003). The objective of this study was to evaluate the inclusion of dry residue of cassava in broiler diets with or without carbohydrase supplementation on performance, carcass yield, cuts and organ quality, blood parameters and meat quality.

\section{Material and Methods}

This work was carried out in the poultry sector of the Experimental Station of the State University of the West of Paraná - UNIOESTE. The experiments were approved by the ethics and biosafety committee of the institution, according to Protocol $N^{\circ} 19 / 13$. The birds were housed in a box (experimental unit - EU) with a tubular feeder, a nipple type water fountain, a heating source (250 watt infrared lamps) and a concrete floor coated with pine wood.

A total of 1,100 one-day-old Cobb 500 male broiler chicks were distributed in a completely randomised design in a $2 \times 5$ factorial scheme consisting of the combination of the addition of carbohydrases and five inclusion levels of DRC ( 0 , $2.5,5.0,7.5$ and $10 \%$ ), resulting in 10 treatments with five replicates and 22 birds each.

Dry residue of cassava and enzyme supplementation were used in poultry rations from 1 to 21 days of age. Feed and water were provided ad libito and illumination (natural and artificial) was 24 hours.

The experimental diets, isoproteic and isocaloric, were formulated with corn and soybean meal according to the food composition and nutritional requirements proposed by Rostagno et al. (2011) for phases 1 to 7 (Table 1) and 8 to 21 (Table 2) days of age for broiler chickens. The DRC used had $89.86 \%$ of dry matter (DM), $0.98 \%$ of crude protein (CP), $3,519 \mathrm{kcal} \mathrm{kg}^{-1}$ of gross energy (GE), $0.19 \%$ of ether extract (EE), $27 \%$ of neutral detergent fiber (NDF), $19.5 \%$ of acid detergent fiber (ADF) in the natural composition.

Carbohydrate inclusion was performed according to the manufacturer's recommendation: Ronozyme $A \circledast$, amylase-based enzyme with inclusion of $0.04 \%$ (400 $\mathrm{g} \mathrm{ton}^{-1}$ of feed), Ronozyme VP®, xylanase with inclusion of $0.02 \%$ (200 $\mathrm{g} \mathrm{ton}^{-1}$ of feed) and Ronozyme WX $2000 \AA$, a beta-glucanase enzyme with inclusion of $0.005 \%$ (50 $\mathrm{g} \mathrm{ton}^{-1}$ of feed). For the use of carbohydrases, metabolizable energy was valued at $50 \mathrm{kcal} \mathrm{kg}^{-1}$.

Feed weight and consumption were recorded at 7,21 and 42 days of age to evaluate the zootechnical performance of the birds. Mortality was determined daily for the correction of feed intake and feed conversion, according to Sakomura and Rostagno (2007).

At 21 days of age, two birds per experimental unit (EU) were randomly chosen, fasted for 6 hours, and blood samples were collected via brachial puncture. The samples were centrifuged and the serum separated and frozen for analysis of cholesterol, triglycerides (TGY), glucose, total protein, creatinine, uric acid (UA), aspartate aminotransferase (AST), alanine aminotransferase (ALT) and gamma-glutamyltransferase (GammaGT). The readings were performed using commercial kits, Elitech, and an automatic spectrophotometer with automatic calibration and high performance reading (Flexor Biochemical Analyzer EL 200).

In the period from 22 to 42 days, the animals received the same ration, the so-called "control ration" (CR), without inclusion of DRC and without carbohydrase supplementation. The growth and finishing rations were formulated with corn and 
soybean meal to meet the requirements of broiler chickens from 22 to 35 and 36 to 42 days of age (ROSTAGNO et al., 2011).

At 42 days of age, four birds per EU, with mean group weight $( \pm 5 \%)$, were individually weighed and killed by cervical dislocation and subsequent bleeding, in accordance with CFMV Resolution No. 1000/2012. The animals were slaughtered according to Normative Instruction $\mathrm{N}^{\circ} .3$ of January
17, 2000, of the DSA/MAPA, which establishes the methods of desensitisation for humanitarian abatement. Subsequently, carcass yield, yield of breast, thigh, overcoat, wing and back, relative liver weight without the gallbladder and empty gizzard were determined. The percentage of abdominal fat was obtained from fat removed from the cloaca and around the gizzard.

Table 1. Percentage and calculated composition of the experimental diets used during the pre-initial phase, 1 to 7 age old days, for broiler chick.

\begin{tabular}{|c|c|c|c|c|c|c|c|c|c|c|}
\hline \multirow{2}{*}{ Ingredient (\%) } & \multicolumn{5}{|c|}{ Diets without carboydrases } & \multicolumn{5}{|c|}{ Diets with carboydrases } \\
\hline & 0.0 & 2.5 & 5.0 & 7.5 & 10.0 & 0.0 & 2.5 & 5.0 & 7.5 & 10.0 \\
\hline Corn & 54.72 & 50.66 & 46.0 & 42.54 & 38.49 & 55.74 & 51.68 & 47.63 & 43.57 & 39.52 \\
\hline Soybean meal 45\% & 36.57 & 37.27 & 37.98 & 38.68 & 39.38 & 36.39 & 37.09 & 37.80 & 38.50 & 39.20 \\
\hline Poultry by-product meal & 2.50 & 2.50 & 2.50 & 2.50 & 2.50 & 2.50 & 2.50 & 2.50 & 2.50 & 2.50 \\
\hline Soybean oil & 2.08 & 2.96 & 3.85 & 4.73 & 5.62 & 1.16 & 2.05 & 2.93 & 3.81 & 4.70 \\
\hline DRC & 0.00 & 2.50 & 5.00 & 7.50 & 10.00 & 0.00 & 2.50 & 5.00 & 7.50 & 10.00 \\
\hline Monobicalcium phosphate & 1.58 & 1.58 & 1.59 & 1.58 & 1.59 & 1.58 & 1.58 & 1.59 & 1.59 & 1.59 \\
\hline Limestone & 0.85 & 0.83 & 0.82 & 0.80 & 0.79 & 0.85 & 0.83 & 0.82 & 0.80 & 0.79 \\
\hline Common salt & 0.48 & 0.48 & 0.49 & 0.48 & 0.49 & 0.48 & 0.48 & 0.49 & 0.49 & 0.49 \\
\hline Byo-Lys (51.7\%) & 0.439 & 0.419 & 0.399 & 0.378 & 0.358 & 0.444 & 0.424 & 0.400 & 0.383 & 0.363 \\
\hline DL-Methionine (98\%) & 0.341 & 0.345 & 0.349 & 0.353 & 0.357 & 0.340 & 0.344 & 0.348 & 0.352 & 0.356 \\
\hline L-Threonine (99\%) & 0.089 & 0.089 & 0.089 & 0.089 & 0.089 & 0.089 & 0.089 & 0.089 & 0.089 & 0.089 \\
\hline L-Valine (99\%) & 0.047 & 0.047 & & 0.046 & 0.045 & 0.047 & 0.047 & 0.046 & 0.046 & 0.045 \\
\hline Vitaminic $^{1}$ & 0.120 & 0.120 & 0.120 & 0.120 & 0.120 & 0.120 & 0.120 & 0.120 & 0.120 & 0.120 \\
\hline Choline chloride (60\%) & 0.060 & 0.060 & 0.060 & 0.060 & 0.060 & 0.060 & 0.060 & 0.060 & 0.060 & 0.060 \\
\hline Salinomycin \% & 0.055 & 0.055 & 0.055 & 0.055 & 0.055 & 0.055 & 0.055 & 0.055 & 0.055 & 0.055 \\
\hline Mineral $^{2}$ & 0.050 & 0.050 & 0.050 & 0.050 & 0.050 & 0.050 & 0.050 & 0.050 & 0.050 & 0.050 \\
\hline BHT & 0.010 & 0.010 & 0.010 & 0.010 & 0.010 & 0.010 & 0.010 & 0.010 & 0.010 & 0.010 \\
\hline Avilamycin \% & 0.005 & 0.005 & 0.005 & 0.005 & 0.005 & 0.005 & 0.005 & 0.005 & 0.005 & 0.005 \\
\hline Carboydrases $^{3}$ & 0.000 & 0.000 & 0.000 & 0.000 & 0.000 & 0.065 & 0.065 & 0.065 & 0.065 & 0.065 \\
\hline \multicolumn{11}{|l|}{ Calculated composition } \\
\hline Metabolizable energy $\left(\mathrm{kcal} \mathrm{kg}^{-1}\right)$ & 2,960 & 2,960 & 2,960 & 2,960 & 2,960 & 2,960 & 2,960 & 2,960 & 2,960 & 2,960 \\
\hline Crude protein $(\%)$ & 22.60 & 22.60 & 22.60 & 22.60 & 22.60 & 22.60 & 22.60 & 22.60 & 22.60 & 22.60 \\
\hline Calcium(\%) & 0.92 & 0.92 & 0.92 & 0.92 & 0.92 & 0.92 & 0.92 & 0.92 & 0.92 & 0.92 \\
\hline Available phosphorus (\%) & 0.47 & 0.47 & 0.47 & 0.47 & 0.47 & 0.47 & 0.47 & 0.47 & 0.47 & 0.47 \\
\hline Sodium (\%) & 0.22 & 0.22 & 0.22 & 0.22 & 0.22 & 0.22 & 0.22 & 0.22 & 0.22 & 0.22 \\
\hline Dig. lysine (\%) & 1.32 & 1.32 & 1.32 & 1.32 & 1.32 & 1.32 & 1.32 & 1.32 & 1.32 & 1.32 \\
\hline Dig. met+ cyst (\%) & 0.95 & 0.95 & 0.95 & 0.95 & 0.95 & 0.95 & 0.95 & 0.95 & 0.95 & 0.95 \\
\hline
\end{tabular}


Continuation...

Dig. threonine $(\%)$

Dig. trypt. (\%)

Dig. valine (\%)

Dig. isoleucine (\%)

$\begin{array}{llllllllll}0.86 & 0.86 & 0.86 & 0.86 & 0.86 & 0.86 & 0.86 & 0.86 & 0.86 & 0.86 \\ 0.25 & 0.25 & 0.25 & 0.25 & 0.25 & 0.25 & 0.25 & 0.25 & 0.25 & 0.25 \\ 1.02 & 1.02 & 1.02 & 1.02 & 1.02 & 1.02 & 1.02 & 1.02 & 1.02 & 1.02 \\ 0.89 & 0.89 & 0.89 & 0.89 & 0.89 & 0.89 & 0.89 & 0.89 & 0.89 & 0.89\end{array}$

${ }^{1}$ Vitaminic premix for birds (Lot BR00014639), Levels per kilogram product: Vit. A (min) 9000000 UI, Vit. D3 (min) 2500000 UI, Vit. E (min) 200000 UI, Vit. K3 (min) 2500 mg, Vit. B1 (min) 1500 mg, Vit. B2(min) 6000 mg, Vit. B6 (min) 3000 mg, Vit. B12 (min) $12000 \mu \mathrm{g}$. Pantothenic acid (min) 12 g, Niacin (min) 25g, Folic acid (min) 800 mg, Biotin (min) $60 \mathrm{mg}$, Selenium (min) $250 \mathrm{mg} .{ }^{2}$ ROLIGOMIX - Mineral premix for birds (Lot BR00013863), Levels per kilogram product: Copper (min) 20g, Iron (min) 100g, Manganese (min) 160g, Cobalt (min) $2000 \mathrm{mg}$, Iodine (min) $2000 \mathrm{mg}$, Zinc (min) 100g. ${ }^{3}$ Carboydrases - Ronozyme $\mathrm{A}^{\circledR}$ (400 g ton ${ }^{-1}$ de ração), Ronozyme $\mathrm{VP}^{\circledR}\left(200 \mathrm{~g}^{\text {ton }}{ }^{-1}\right.$ de ração) e Ronozyme WX $2000^{\circledR}\left(50 \mathrm{~g}^{\text {ton }}{ }^{-1}\right.$ de ração).

Meat quality was evaluated in the right and left breast muscle (pectoralis major) of two birds per EU. The $\mathrm{pH}$ was determined directly on the right chest fillet, $15 \mathrm{~min}$ and $24 \mathrm{~h}$ "post mortem" (OLIVO et al., 2001), with the help of the HI 99163 portable peg diameter.

Breast colour was measured $15 \mathrm{~min}$ and $24 \mathrm{~h}$ and 15 min post-mortem, using the portable CR-
400 colorimeter (Konica Minolta Sensing, São Paulo, Brazil). The components L * (luminosity dark to light level), a * (intensity of red/green) and b* (intensity of yellow/blue) were expressed in the Cielab colour system.

The left breast muscle was used to evaluate water retention capacity in the carcass (WRC), weight loss by cooking (WLC) and shear force (SF).

Table 2. Percentage and calculated composition of the experimental diets used during the initial phase, 8 to 21 age old days, for broiler chick.

\begin{tabular}{lccccccccccc}
\hline \multirow{2}{*}{ Ingredient } & \multicolumn{4}{c}{ Diets without carboydrases } & \multicolumn{4}{c}{ Diets with carboydrases } \\
\cline { 2 - 11 } & 0.0 & 2.5 & 5.0 & 7.5 & 10.0 & 0.0 & 2.5 & 5.0 & 7.5 & 10.0 \\
\hline Corn & 57.49 & 53.47 & 49.44 & 45.42 & 41.39 & 58.51 & 54.45 & 50.46 & 46.44 & 42.41 \\
Soybean meal 45\% & 30.58 & 31.26 & 31.93 & 32.60 & 33.28 & 30.41 & 31.09 & 31.76 & 32.44 & 33.11 \\
Poultry by-product meal & 5.00 & 5.00 & 5.00 & 5.00 & 5.00 & 5.00 & 5.00 & 5.00 & 5.00 & 5.00 \\
DRC & 0.00 & 2.50 & 5.00 & 7.50 & 10.00 & 0.00 & 2.50 & 5.00 & 7.50 & 10.00 \\
Soybean oil & 2.72 & 3.60 & 4.48 & 5.36 & 6.24 & 1.80 & 2.69 & 3.56 & 4.44 & 5.32 \\
Dicalcium Phosphate & 0.93 & 0.93 & 0.93 & 0.93 & 0.93 & 0.93 & 0.93 & 0.93 & 0.93 & 0.93 \\
Limestone & 0.81 & 0.79 & 0.78 & 0.76 & 0.75 & 0.81 & 0.79 & 0.78 & 0.76 & 0.75 \\
Common salt & 0.44 & 0.44 & 0.44 & 0.44 & 0.44 & 0.44 & 0.44 & 0.44 & 0.44 & 0.44 \\
ByoLys (51.7\%) & 0.408 & 0.389 & 0.370 & 0.350 & 0.330 & 0.413 & 0.393 & 0.374 & 0.355 & 0.336 \\
DL-Methionine (98\%) & 0.276 & 0.280 & 0.285 & 0.289 & 0.293 & 0.275 & 0.279 & 0.283 & 0.287 & 0.292 \\
L-Threonine (99\%) & 0.055 & 0.055 & 0.055 & 0.055 & 0.056 & 0.055 & 0.055 & 0.055 & 0.055 & 0.055 \\
Vitaminic $^{1}$ & 0.100 & 0.100 & 0.100 & 0.100 & 0.100 & 0.100 & 0.100 & 0.100 & 0.100 & 0.100 \\
Choline chloride (60\%) & 0.060 & 0.060 & 0.060 & 0.060 & 0.060 & 0.060 & 0.060 & 0.060 & 0.060 & 0.060
\end{tabular}


Continuation...

\begin{tabular}{|c|c|c|c|c|c|c|c|c|c|c|}
\hline Salinomycin \% & 0.055 & 0.055 & 0.055 & 0.055 & 0.055 & 0.050 & 0.055 & 0.055 & 0.055 & 0.055 \\
\hline Mineral $^{2}$ & 0.050 & 0.050 & 0.050 & 0.050 & 0.050 & 0.050 & 0.050 & 0.050 & 0.050 & 0.050 \\
\hline BHT & 0.010 & 0.010 & 0.010 & 0.010 & 0.010 & 0.010 & 0.010 & 0.010 & 0.010 & 0.010 \\
\hline Avilamycin \% & 0.005 & 0.005 & 0.005 & 0.005 & 0.005 & 0.005 & 0.005 & 0.050 & 0.005 & 0.005 \\
\hline Carboydrases $^{3}$ & 0.000 & 0.000 & 0.000 & 0.000 & 0.000 & 0.065 & 0.065 & 0.065 & 0.065 & 0.065 \\
\hline Celite (indicator) & 1.000 & 1.000 & 1.000 & 1.000 & 1.000 & 1.000 & 1.000 & 1.000 & 1.000 & 1.000 \\
\hline \multicolumn{11}{|l|}{ Calculated composition } \\
\hline Metabolizable energy $\left(\mathrm{kcal} \mathrm{kg}^{-1}\right)$ & 3,050 & 3,050 & 3,050 & 3,050 & 3,050 & 3,050 & 3,050 & 3,050 & 3,050 & 3,050 \\
\hline Crude protein $(\%)$ & 21.45 & 21.44 & 21.43 & 21.42 & 21.41 & 21.45 & 21.44 & 21.43 & 21.42 & 21.41 \\
\hline Calcium(\%) & 0.84 & 0.84 & 0.84 & 0.84 & 0.84 & 0.84 & 0.84 & 0.84 & 0.84 & 0.84 \\
\hline Available phosphorus (\%) & 0.40 & 0.40 & 0.40 & 0.40 & 0.40 & 0.40 & 0.40 & 0.40 & 0.40 & 0.40 \\
\hline Dig. lysine $(\%)$ & 1.21 & 1.21 & 1.21 & 1.21 & 1.21 & 1.21 & 1.21 & 1.21 & 1.21 & 1.21 \\
\hline Sodium $(\%)$ & 0.21 & 0.21 & 0.21 & 0.21 & 0.21 & 0.21 & 0.21 & 0.21 & 0.21 & 0.21 \\
\hline Dig. met + cyst $(\%)$ & 0.87 & 0.87 & 0.87 & 0.87 & 0.87 & 0.87 & 0.87 & 0.87 & 0.87 & 0.87 \\
\hline Dig. threonine (\%) & 0.79 & 0.79 & 0.79 & 0.79 & 0.79 & 0.79 & 0.79 & 0.79 & 0.79 & 0.79 \\
\hline Dig. tryptophan (\%) & 0.23 & 0.23 & 0.23 & 0.23 & 0.23 & 0.23 & 0.23 & 0.23 & 0.23 & 0.23 \\
\hline Dig. valine (\%) & 0.93 & 0.93 & 0.93 & 0.93 & 0.93 & 0.93 & 0.93 & 0.93 & 0.93 & 0.93 \\
\hline Dig. isoleucine (\%) & 0.84 & 0.84 & 0.84 & 0.84 & 0.84 & 0.84 & 0.84 & 0.84 & 0.84 & 0.84 \\
\hline
\end{tabular}

${ }^{1}$ Vitaminic premix (Lot BR00014639), Levels per kilogram product: Vit. A (min) 9000000 UI, Vit. D3 (min) 2500000 UI, Vit. E (min) 20000 UI, Vit. K3 (min) 2500 mg, Vit. B1 (min) 1500 mg, Vit. B2 (min) 6000 mg, Vit. B6 (min) 3000 mg, Vit. B12 (min) $12000 \mu \mathrm{g}$, Pantothenic acid (min) $12 \mathrm{~g}$, Niacin (min) 25g, Folic acid (min) $800 \mathrm{mg}$, Biotin (min) $60 \mathrm{mg}$, Selenium (min) $250 \mathrm{mg}$. ${ }^{2}$ ROLIGOMIX - Mineral premix (Lot BR00013863), Levels per kilogram product: Copper (min) 20g, Iron (min) 100g, Manganese (min) 160g, Cobalt (min) $2000 \mathrm{mg}$, Iodine (min) $2000 \mathrm{mg}$, Zinc (min) 100g. ${ }^{3}$ Carboydrases - Ronozyme $\mathrm{A}^{\circledR}$ (400 g ton ${ }^{-1}$ de ração), Ronozyme $\mathrm{VP}^{\circledR}\left(200 \mathrm{~g}^{\text {ton }}{ }^{-1}\right.$ de ração) e Ronozyme WX $2000^{\circledR}$ (50 g ton ${ }^{-1}$ de ração).

The WRC was performed by centrifugation as proposed by Nakamura and Katok (1985). Samples of approximately $1 \mathrm{~g}$ of chest muscle (pectoralis major) "in natura" were wrapped in filter paper, centrifuged at 2,000 rpm for $4 \mathrm{~min}$, weighed, ovendried at $70^{\circ} \mathrm{C}$ for $12 \mathrm{~h}$ and weighed again for WRC calculation. For the determination of the WLC, the breast fillets were weighed, packed in laminated paper and baked in commercial plates at $180^{\circ} \mathrm{C}$ until reaching an internal temperature of $80^{\circ} \mathrm{C}$ in the centre of the sample. Subsequently, the samples were allowed to stabilise at room temperature and then weighed again (HONIKEL, 1998). For the SF analysis, the samples were cut into three rectangles $(1.0 \times 1.0 \times 2.0 \mathrm{~cm})$ and placed with the fibers oriented perpendicular to the blade to determine HR in kilograms $\left(\mathrm{kgf} \mathrm{cm}^{-2}\right)$, using a Brookifield CT3
Texture Analyzer, coupled with a TA 3/100 probe, TA - SBA fixture, calibrated at $0.01 \mathrm{~kg}$ force, $20 \mathrm{~mm}$ strain, $2.5 \mathrm{~mm} \mathrm{~s}^{-1}$ test velocity.

Analysis of variance and subsequent polynomial regression were performed between inclusion levels, excluding basal ration ( $0 \%$ DRC). In addition, the Dunnett test was applied at $5 \%$ probability to compare the basal diet with the other treatments. Statistical analyzes were performed using the SAEG - System for Statistical and Genetic Analysis (UFV, 1997).

\section{Results and Discussion}

There was an interaction $(\mathrm{P}<0.05)$ between carbohydrase supplementation and the different 
inclusion levels of DRC for weight gain (WG) and feed intake (FI) (Table 3). Without carbohydrase inclusion, WG and FI showed a linear decreasing behaviour. However, with the addition of carbohydrases, no effect was observed $(\mathrm{P}>0.05)$.

Table 3. Supplementation or no carbohydrases and inclusion levels of dry residue of cassava in the performance of broiler chick from 1 to 21 age old days.

\begin{tabular}{|c|c|c|c|c|c|c|}
\hline \multirow[b]{2}{*}{ Inclusion (\%) } & \multicolumn{2}{|c|}{ Weight gain $(\mathrm{g})$} & \multicolumn{2}{|c|}{ Feed intake $(\mathrm{g})$} & \multicolumn{2}{|c|}{ Feed conversion } \\
\hline & $\begin{array}{l}\text { Without } \\
\text { CHO'se }\end{array}$ & $\begin{array}{c}\text { With } \\
\text { CHO'se }\end{array}$ & $\begin{array}{l}\text { Without } \\
\text { CHO'se }\end{array}$ & $\begin{array}{c}\text { With } \\
\text { CHO'se }\end{array}$ & $\begin{array}{l}\text { Without } \\
\text { CHO'se }\end{array}$ & $\begin{array}{c}\text { With } \\
\text { CHO'se }\end{array}$ \\
\hline 0.0 & 947 & 935 & 1346 & 1344 & 1.355 & 1.373 \\
\hline 2.5 & 934 & 930 & $1307^{*}$ & 1311 & 1.343 & 1.346 \\
\hline 5.0 & 933 & 928 & $1297^{*}$ & $1305^{*}$ & 1.322 & 1.342 \\
\hline 7.5 & $909 *$ & 920 & $1272 *$ & $1265^{*}$ & 1.334 & 1.347 \\
\hline 10.0 & $881 *$ & 934 & $1241 *$ & $1298 *$ & 1.341 & 1.327 \\
\hline Means & 9201 & 929 & 1293 & 1305 & 1.339 & 1.340 \\
\hline Cho'se & \multicolumn{2}{|c|}{0.182} & \multicolumn{2}{|c|}{0.106} & \multicolumn{2}{|c|}{0.965} \\
\hline Inclusion & \multicolumn{2}{|c|}{0.007} & \multicolumn{2}{|c|}{$<0.001$} & \multicolumn{2}{|c|}{0.244} \\
\hline Interaction & \multicolumn{2}{|c|}{0.014} & \multicolumn{2}{|c|}{0.043} & \multicolumn{2}{|c|}{0.457} \\
\hline CV (\%) & \multicolumn{2}{|c|}{2.344} & \multicolumn{2}{|c|}{1.907} & \multicolumn{2}{|c|}{2.190} \\
\hline EPM & \multicolumn{2}{|c|}{4.425} & \multicolumn{2}{|c|}{5.474} & \multicolumn{2}{|c|}{0.005} \\
\hline Interaction & \multicolumn{2}{|c|}{0.025} & \multicolumn{2}{|c|}{0.036} & \multicolumn{2}{|c|}{0.364} \\
\hline Inclusion & \multicolumn{2}{|c|}{0.058} & \multicolumn{2}{|c|}{0.001} & \multicolumn{2}{|c|}{0.949} \\
\hline Linear & $<0.001^{1}$ & - & $<0.001^{2}$ & 0.120 & - & - \\
\hline Quadratic & 0.185 & - & 0.355 & 0.094 & - & - \\
\hline
\end{tabular}

Cho'se: carboydrases

* Means followed by * differ to inclusion level " 0 " by the Dunnett test, at the $5 \%$ probability level; ${ }^{1} \mathrm{Y}=-7,32 * \mathrm{DRC}+960\left(\mathrm{R}^{2}=0,84\right)$; ${ }^{2} \mathrm{Y}=-8.92 * \mathrm{DRC}+1335\left(\mathrm{R}^{2}=0,93\right)$.

There was a linear reduction $(\mathrm{P}<0.05)$ in the WG of the animals with increased DRC inclusion without carbohydrase inclusion. Inclusion levels of 7.5 and $10 \%$ differed $(\mathrm{P}<0.05)$ from the control treatment by the Dunnett test, presenting a lower WG in relation to the control. Supplementation with carbohydrases provided birds with a WG similar to those that did not receive supplementation.

It can be inferred that carbohydrase supplementation was responsible for overcoming the negative effects of DRC, providing similar performance among birds. According to Sartori et al. (2007), exogenous enzymes have the ability to maintain or even improve the performance of animals by helping to digest substandard products. These benefits are related to improvements in the digestion process and absorption of the undigested fraction of dietary starch and fat and the regulation of several digestive secretions (ROMERO et al., 2013).

Inclusion of DRC without the addition of carbohydrates in the diet caused a linear reduction $(\mathrm{P}<0.05)$ in the FI with the increase of inclusion levels. This may have occurred because increased inclusion of DRC provides an increase in the amount of dietary fiber, resulting in a higher 
viscosity of the digesta, thus reducing consumption and, consequently, nutrient digestibility and bird performance.

With carbohydrase supplementation, the reduction of FI was not that significant with the increase of the DRC inclusion levels. Carbohydrases contributed to an improvement in consumption up to the inclusion level of $2.5 \%$ of DRC; from the $5 \%$ inclusion level, there was a decrease in consumption in relation to the control ration by the Dunnett test $(\mathrm{P}<0.05)$. There was no difference $(\mathrm{P}>0.05)$ in feed conversion (FC).

According to Calderano et al. (2010) and González-Alvarado et al. (2007), decreased WG and FI levels with increased DRC inclusion levels may be related to the increased fibre content in the diet, combined with the low digestion capacity, as well as the sensation of satiety caused by the fibre.

Dry residue of cassava, because of its high content of acid-detergent fibre (ADF), may be responsible for increasing water absorption capacity of the diet, with an increase in feed density. The results of this work show that the fibre content of the diets increased with increasing inclusion levels of DRC, which may have led to a greater drag and a lower nutrient use (SOUSA et al., 2014).

Between 1 to 42 days of age, there was an interaction $(\mathrm{P}<0.05)$ between carbohydrase supplementation and inclusion level of RSF for the variables WG and FC; however, these did not fit the proposed polynomial model (Table 4).

Table 4. Supplementation or no carbohydrases and inclusion levels of dry residue of cassava in the performance of broiler chicken from 1 to 42 age old days.

\begin{tabular}{|c|c|c|c|c|c|c|}
\hline \multirow[b]{2}{*}{ Inclusion (\%) } & \multicolumn{2}{|c|}{ Weight gain $(\mathrm{g})$} & \multicolumn{2}{|c|}{ Feed intake $(\mathrm{g})$} & \multicolumn{2}{|c|}{ Feed conversion } \\
\hline & $\begin{array}{l}\text { Without } \\
\text { CHO'se }\end{array}$ & $\begin{array}{c}\text { With } \\
\text { CHO'se }\end{array}$ & $\begin{array}{l}\text { Without } \\
\text { CHO'se }\end{array}$ & $\begin{array}{c}\text { With } \\
\text { CHO'se }\end{array}$ & $\begin{array}{l}\text { Without } \\
\text { CHO'se }\end{array}$ & $\begin{array}{c}\text { With } \\
\text { CHO'se }\end{array}$ \\
\hline 0.0 & 2795 & 2688 & 4495 & 4413 & 1.583 & 1.615 \\
\hline 2.5 & $2669 *$ & 2712 & 4473 & 4404 & $1.648^{*}$ & 1.598 \\
\hline 5.0 & $2695^{*}$ & 2706 & 4467 & 4431 & $1.631^{*}$ & 1.611 \\
\hline 7.5 & $2664 *$ & 2727 & 4420 & 4365 & $1.632 *$ & 1.575 \\
\hline 10.0 & $2694 *$ & 2725 & 4533 & 4405 & $1.655^{*}$ & 1.590 \\
\hline Means & 2704 & 2711 & 4477 & 4404 & 1.630 & 1.598 \\
\hline CHO'se & \multicolumn{2}{|c|}{0.496} & \multicolumn{2}{|c|}{0.002} & \multicolumn{2}{|c|}{0.001} \\
\hline Inclusion & \multicolumn{2}{|c|}{0.025} & \multicolumn{2}{|c|}{0.248} & \multicolumn{2}{|c|}{0.156} \\
\hline Interaction & \multicolumn{2}{|c|}{$<0.001$} & \multicolumn{2}{|c|}{0.737} & \multicolumn{2}{|c|}{0.011} \\
\hline CV (\%) & \multicolumn{2}{|c|}{1.183} & \multicolumn{2}{|c|}{1.739} & \multicolumn{2}{|c|}{2.048} \\
\hline EPM & \multicolumn{2}{|c|}{9.485} & \multicolumn{2}{|c|}{11.990} & \multicolumn{2}{|c|}{0.006} \\
\hline Interaction & \multicolumn{2}{|c|}{0.578} & \multicolumn{2}{|c|}{0.593} & \multicolumn{2}{|c|}{0.441} \\
\hline Inclusion & \multicolumn{2}{|c|}{0.767} & \multicolumn{2}{|c|}{0.181} & \multicolumn{2}{|c|}{0.473} \\
\hline Linear & \multicolumn{2}{|c|}{0.384} & \multicolumn{2}{|c|}{0.752} & \multicolumn{2}{|c|}{0.687} \\
\hline Quadratic & \multicolumn{2}{|c|}{0.869} & \multicolumn{2}{|c|}{0.191} & \multicolumn{2}{|c|}{0.300} \\
\hline
\end{tabular}

CHO'se: carboydrase

* Means followed by * differ to inclusion level " 0 " by the Dunnett test, at the $5 \%$ probability level. 
In terms of $\mathrm{WG}$ and $\mathrm{FC}$, the birds that received no carbohydrase supplementation from the $2.5 \%$ inclusion level of the DRC presented a difference $(\mathrm{P}<0.05)$ in relation to the control ration. The inclusion of DRC was responsible for the decrease in WG and worsening in the FC.

With carbohydrase supplementation, the variables WG, FI and $\mathrm{FC}$ did not differ $(\mathrm{P}>$ 0.05) from those obtained with the control diet. However, carbohydrates may have contributed to the availability of DRC nutrients, since their inclusion resulted in a similar animal performance compared to the group that did not receive such supplementation.

The use of co-products or ingredients of inferior nutritional quality may adversely affect the performance of broilers; however, when combined with carbohydrases, this effect can be mitigated or reversed.

It is likely that carbohydrases facilitate the digestibility of fibre and starch, thereby improving nutrient absorption and favouring high bird performance. According to Bedford and Apajalahti (2001), such high performance obtained with the use of a combination of carbohydrases is a result of the improvement in nutrient use and the balance of the intestinal microbial population of the birds.

Regarding the variables carcass, breast, thigh, overcoat and wing performance, these were not influenced $(\mathrm{P}>0.05)$ by carbohydrase supplementation and inclusion levels of DRC between 1 and 21 days (Table 5).

Table 5. Carcass yield and cuts of broiler chicken from 1 to 42 age old days feed dry residue of cassava with or without carbohydrase supplementation.

\begin{tabular}{lccccc}
\hline CHO'se & Carcass (\%) & Breast (\%) & Thigh (\%) & Overcoat (\%) & Wing (\%) \\
\hline Without & 72.20 & 39.24 & 13.73 & 16.60 & 10.88 \\
With & 72.94 & 39.50 & 13.73 & 16.77 & 10.86 \\
\hline P & 0.074 & 0.542 & 0.999 & 0.520 & 0.880 \\
\hline Inclusion (\%) & & & & & \\
\hline 0.0 & 72.50 & 39.95 & 13.78 & 16.49 & 10.80 \\
2.5 & 73.02 & 39.49 & 13.64 & 16.82 & 10.89 \\
5.0 & 72.47 & 39.56 & 13.74 & 16.85 & 10.82 \\
7.5 & 73.03 & 39.50 & 13.35 & 16.47 & 10.66 \\
10.0 & 71.84 & 38.34 & 14.15 & 16.79 & 11.17 \\
\hline Dunnett & 0.332 & 0.196 & 0.100 & 0.778 & 0.292 \\
Interaction & 0.187 & 0.531 & 0.069 & 0.467 & 0.881 \\
CV (\%) & 2.800 & 5.516 & 6.466 & 7.571 & 6.836 \\
\hline Inclusion & 0.237 & 0.266 & 0.060 & 0.746 & 0.215 \\
Interaction & 0.165 & 0.466 & 0.054 & 0.325 & 0.791 \\
\hline
\end{tabular}

CHO'se: carboydrases.

Although bird performance was adversely the amino acid balance of the diets being adequate, affected by the inclusion of DRC, carcass yield and since amino acids participate in the composition cuts were similar. This may have occurred due to of muscle protein (BARBOZA et al., 2000). In 
addition, the energetic contents of the different treatments were kept similar, according to the recommendation of the phase.

These results demonstrate that DRC does not affect carcass characteristics and weight of the main cuts when the diet is properly balanced. The results of this study are in agreement with those of Cardoso et al. (2011), who evaluated the effect of enzyme complex use on broiler feeds and did not find differences in carcass yield and cut rates. Similarly, Torres et al. (2003) and Ferreira et al. (2012) did not observe a positive effect of exogenous enzymes on the analysed variables.

There was no interaction $(\mathrm{P}>0.05)$ between carbohydrase supplementation and inclusion level of DRC in terms of percentage of abdominal fat and organ yield (Table 6).

Table 6. Relative weight of organs and percentage of abdominal fat of broiler chicken to 42 old age days feed dry residue of cassava supplemented or without carbohydrases.

\begin{tabular}{lcccc}
\hline CHO'se & Abdominal fat (\%) & Gizzard (\%) & Liver (\%) & Intestine (\%) \\
\hline Without & 1.27 & $1.48^{\mathrm{b}}$ & 1.86 & 5.21 \\
With & 1.21 & $1.67^{\mathrm{a}}$ & 1.85 & 4.92 \\
\hline $\mathrm{P}$ & 0.417 & 0.026 & 0.611 & 0.089 \\
\hline Inclusion (\%) & & & & 4.97 \\
\hline 0.0 & 1.23 & 1.53 & 1.80 & 4.95 \\
2.5 & $1.46^{*}$ & 1.45 & 1.82 & 5.33 \\
5.0 & 1.19 & 1.70 & 1.97 & 5.01 \\
7.5 & 1.22 & 1.55 & 1.85 & 5.06 \\
10.0 & 1.11 & 1.65 & 1.86 & 0.419 \\
\hline Dunnett & 0.021 & 0.302 & 0.368 & 0.260 \\
Interaction & 0.218 & 0.210 & 0.606 & 16.725 \\
CV (\%) & 26.496 & 25.659 & 15.721 & 0.533 \\
\hline Interaction & 0.159 & 0.195 & 0.611 & 0.520 \\
\hline Inclusion & 0.015 & 0.204 & 0.365 & 0.975 \\
Linear & $0.004^{1}$ & 0.275 & 0.965 & 0.387 \\
Quadratic & 0.310 & 0.394 & 0.266 & \\
\hline
\end{tabular}

CHO'se: carboydrase

* Means followed by * differ to inclusion level " 0 " by the Dunnett test. at the $5 \%$ probability level;

$\mathrm{AF}=-0.020225 \mathrm{DRC}+1.4969\left(\mathrm{R}^{2}=0.77\right)$.

Percentage of abdominal fat and relative liver and intestine weight were not significantly different $(\mathrm{P}>0.05)$ between supplemented or nonsupplemented birds. In relation to the gizzard presented higher relative weight in the chickens that received carbohydrase supplementation.

Inclusion of DRC had a linear decreasing effect on the percentage of abdominal fat. The inclusion level of $2.5 \%$ presented a difference $(\mathrm{P}<0.05)$ in relation to the control ration by the Dunnett test, with an increase in the percentage of abdominal fat at this level.

Similarly, Torres et al. (2003), analysing the efficiency of enzymes (amylase, xylanase and protease) in the production of broilers, did not find significant differences in abdominal fat. 
There was an interaction $(\mathrm{P}<0.05)$ between carbohydrase supplementation and the different inclusion levels of DRC in terms of uric acid. However, this did not fit any predefined model (Table 7).

Carbohydrase inclusion resulted in increased levels of cholesterol, triglycerides, glucose, creatinine, uric acid and gamma GT $(\mathrm{P}<0.05)$ in the blood. Alanine aminotransferase levels were significantly higher without carbohydrase inclusion
$(\mathrm{P}<0.05)$, while AST and total proteins were not influenced by carbohydrase $(\mathrm{P}>0.05)$.

Although the concentrations of these variables increased with carbohydrase inclusion, they are within the reference values described by Schmidt et al. (2007), namely: cholesterol, 100 to $250 \mathrm{mg} \mathrm{dL}$ 1; triglycerides, 37 to $115 \mathrm{mg} \mathrm{dL}^{-1}$; glucose, 200 to $500 \mathrm{mg} \mathrm{dL}^{-1}$; creatinine, 100 to $250 \mathrm{IU} \mathrm{L}-1$; uric acid values, $>15 \mathrm{mg} \mathrm{dL}^{-1}$; GT, 0 to $10 \mathrm{IU} \mathrm{L}^{-1}$.

Table 7. Blood parameters of broiler chick at 21 old age days feed with dry residue of cassava supplemented or without carbohydrases.

\begin{tabular}{|c|c|c|c|c|c|c|c|c|c|}
\hline CHO'se & $\begin{array}{l}\text { Choles- } \\
\text { terol } \\
\left(\mathrm{mg} \mathrm{dL}^{-1}\right)\end{array}$ & $\begin{array}{l}\text { Trigly- } \\
\text { cerides } \\
\left(\mathrm{mg} \mathrm{dL}^{-1}\right)\end{array}$ & $\begin{array}{c}\text { Glu- } \\
\text { cose } \\
\left(\mathrm{mg} \mathrm{dL}^{-1}\right)\end{array}$ & $\begin{array}{c}\text { Total } \\
\text { proteins } \\
\left(\mathrm{g} \mathrm{dL}^{-1}\right)\end{array}$ & $\begin{array}{l}\text { Creati- } \\
\text { nine } \\
\left(\mathrm{mg} \mathrm{dL}^{-1}\right)\end{array}$ & $\begin{array}{c}\text { Uric } \\
\text { acid } \\
\left(\mathrm{mg} \mathrm{dL}^{-1}\right)\end{array}$ & $\begin{array}{c}\text { AST } \\
\left(\mathrm{UI} \mathrm{L}^{-!}\right)\end{array}$ & $\begin{array}{c}\text { ALT } \\
\left(\mathrm{UI} \mathrm{L}^{-1}\right)\end{array}$ & $\begin{array}{l}\text { Gam- } \\
\text { ma GT } \\
\left(\mathrm{UI} \mathrm{L}^{-1}\right)\end{array}$ \\
\hline Without & $104.32^{\mathrm{b}}$ & $26.16^{\mathrm{b}}$ & $199.76^{\mathrm{b}}$ & 2.59 & $0.18^{\mathrm{b}}$ & $1.92^{\mathrm{b}}$ & 150.72 & $17.28^{\mathrm{a}}$ & $6.20^{\mathrm{b}}$ \\
\hline With & $112.08^{\mathrm{a}}$ & $30.84^{\mathrm{a}}$ & $215.28^{\mathrm{a}}$ & 2.63 & $0.20^{\mathrm{a}}$ & $2.66^{\mathrm{a}}$ & 162.20 & $10.84^{\mathrm{b}}$ & $8.60^{\mathrm{a}}$ \\
\hline $\mathrm{P}$ & 0.027 & 0.003 & 0.007 & 0.645 & 0.018 & 0.002 & 0.057 & $<0.001$ & $<0.001$ \\
\hline \multicolumn{10}{|c|}{ Inclusion (\%) } \\
\hline 0.0 & 110.10 & 29.70 & 203.00 & 2.64 & 0.19 & 2.27 & 144.50 & 16.40 & 6.20 \\
\hline 2.5 & 105.40 & 27.20 & 202.90 & 2.48 & $0.17^{*}$ & 2.00 & 147.90 & 14.70 & 6.30 \\
\hline 5.0 & 117.20 & 31.10 & 217.20 & 2.81 & 0.20 & 2.61 & 163.00 & $14.20^{*}$ & $8.40^{*}$ \\
\hline 7.5 & 104.70 & 26.20 & 207.60 & 2.50 & 0.20 & 2.26 & 164.20 & $12.80^{*}$ & $8.10^{*}$ \\
\hline 10.0 & 103.60 & 28.30 & 206.90 & 2.62 & 0.20 & 2.30 & 162.70 & $12.20 *$ & $8.00^{*}$ \\
\hline Dunnett & 0.088 & 0.246 & 0.471 & 0.127 & 0.020 & 0.572 & 0.100 & $<0.001$ & 0.015 \\
\hline Interaction & 0.740 & 0.427 & 0.874 & 0.457 & 0.157 & 0.022 & 0.136 & 0.689 & 0.989 \\
\hline CV $(\%)$ & 11.078 & 18.188 & 9.342 & 11.644 & 10.827 & 34.864 & 13.213 & 14.714 & 24.174 \\
\hline Interaction & 0.564 & 0.271 & 0.894 & 0.818 & 0.060 & 0.135 & 0.492 & 0.637 & 0.985 \\
\hline Inclusion & 0.045 & 0.178 & 0.474 & 0.099 & 0.004 & 0.405 & 0.274 & 0.038 & 0.064 \\
\hline Linear & 0.283 & 0.824 & 0.934 & 0.828 & 0.005 & 0.626 & 0.134 & $0.005^{4}$ & 0.074 \\
\hline Quadratic & $0.048^{2}$ & 0.578 & 0.261 & 0.322 & $0.0241^{3}$ & 0.263 & 0.220 & 0.939 & 0.067 \\
\hline
\end{tabular}

CHO'se: carboydrases;

* Means followed by * differ to inclusion level " 0 " by the Dunnett test. at the $5 \%$ probability level;

${ }^{2} \mathrm{Chol}=96.0750+0.5734 \mathrm{DRC}-0.00516 \mathrm{DRC}^{2}\left(\mathrm{R}^{2}=0.47\right)$;

${ }^{3} \mathrm{Cre}=0.1355+0.0172 \mathrm{DRC}-0.00112 \mathrm{DRC}^{2}\left(\mathrm{R}^{2}=0.92\right) ;$

${ }^{4} \mathrm{ALT}=15.7-0.356 \mathrm{DRC}\left(\mathrm{R}^{2}=0.96\right)$.

According to Alonso-Alvarez et al. (2002), in sea gulls, cholesterol levels are positively correlated with bird weights; which is in agreement with the results found in this work.

Increased values of creatinine and uric acid indicate muscle damage due to catabolism and use of muscle proteins as an energy source (GONZÁLEZ; SCHEFFER, 2002); this was, however, not observed in this study, since these variables increased with increased bird weight.

As DRC is a fibrous food, it can be assumed that the use of carbohydrases has contributed to the 
reduction of antinutritional factors caused by fibre, thus enhancing nutrient digestibility and absorption and increasing the analysed variables.

There was an effect of DRC inclusion $(\mathrm{P}<$ $0.05)$ on creatinine concentration; the $2.5 \%$ DRC level presented a difference when compared to the control ration. The results of the Dunnett test showed that ALT significantly decreased $(\mathrm{P}<0.05)$ with increased DRC levels (5.0, 7.5 and 10\%). At these levels, there was also an increase $(\mathrm{P}<0.05)$ in the GT concentration when compared to the control ration. In contrast, DRC inclusion had no effect ( $P$ $>0.05$ ) on cholesterol, TYG, glucose, total proteins, uric acid and AST.

Although DRC inclusion resulted in decreased creatinine and ALT concentrations and increased GT ranges, these values were still within the reference ranges, i.e. 100 to $250 \mathrm{IU} \mathrm{L}^{-1}$ for creatinine, 19 to 50 IU L ${ }^{-1}$ for ALT (LUMEIJ, 1997) and 0-10 $\mathrm{U} \mathrm{L}^{-1}$ for the GT range (SCHMIDT et al., 2007).

The inclusion of DRC had a quadratic effect on cholesterol levels, and the level that determined the maximum response value was $5.57 \%$. Cholesterol levels increased with a subsequent fall from the 5\% inclusion level of DRC. This could be explained by the increase in the original fibre amount, which may have provided an increase in the viscosity of the food cake and a consequent drop in digestibility, especially in terms of fat.

In addition, inclusion of DRC had a quadratic effect on creatinine levels, and the level that determined the maximum response value was $7.67 \%$. Creatinine is widely used as an indicator of glomerular filtration, originating from muscle creatinine and being excreted with urine after glomerular filtration. Creatinine is less influenced by extra-renal factors and, therefore, would be a more realistic indicator of glomerular filtration rates (GREENE et al., 2006).

There was a negative linear effect of increasing DRC levels on ALT concentrations; ALT is found mainly in the hepatocyte cytoplasm and is considered a specific hepatoid enzyme. In this way, it assists in the diagnosis and prognosis of liver diseases (MOTTA, 2003).

Accelerated bird growth due to genetic selection is responsible for the occurrence of myopathies and the influx of liver enzymes such as creatinine kinase, ALT and AST into the circulatory system. Reducing the growth rate by limiting feeding reduces muscle damage and, consequently, the influx of enzymes (RAJMAN et al., 2006). This could be observed in this study, since birds fed with DRC inclusion without enzymatic supplementation showed lower weight gain, that is, decreased muscular deposition.

According to Savón (2002), fibre and its equivalents in diets act directly on fat metabolism, decreasing intestine absorption capacity for lipids and cholesterol, which can cause reduction in plasma TYG and cholesterol values, since the increase in the viscosity of the food bolus decreases the action of bile salts and increases the excretion of bile salts and dietary lipids (MOURÃO et al., 2005).

Barbosa et al. (2008) reported that enzymes reduce the antinutritional factors of foods, aiding in fibre breakage. As DRC is a fibrous food, it can be inferred that the enzymes caused a reduction in the antinutritional properties of the fibre, improving the digestibility of the diet and the absorption of some nutrients, including cholesterol and lipids, which provided an increase in the analysed variables (CAIRES et al., 2008).

The values of $\mathrm{L}, \mathrm{a} *$ and $\mathrm{b} *$ of the breast meat at 15 minutes post mortem evaluation showed no difference $(\mathrm{P}>0.05)$ with $\mathrm{DRC}$ inclusion and carbohydrase addition. In the 24-hour post-mortem analysis, there was an interaction $(\mathrm{P}<0.05)$ between carbohydrase supplementation and inclusion of DRC for the variable L; however, it did not fit any predefined model. With the inclusion of $2.5 \%$ of DRC, luminosity was decreased $(\mathrm{P}<0.05)$ in relation to CR by Dunnett's test. At other levels of DRC inclusion, there was no difference $(\mathrm{P}>0.05)$, irrespective of the carbohydrase addition (Table 8). 
Colour uniformity is an important attribute because it is indicative of the quality of the final product, thereby influencing selection by customers (QIAO et al., 2002).

Du and Ahn (2002) stated that environmental conditions and food are factors that can affect the colour of meat. In contrast, other studies have shown that meat colour, as opposed to skin colour, is only slightly influenced by the food quality. According to Qiao et al. (2002), meat colour is influenced mainly by the conditions caused by accelerated post-mortem muscle metabolism and is related to heredity.

Qiao et al. (2001) have performed a colour classification for breast meat of broilers. According to this classification, the meat samples in the 15-minute post-mortem evaluation can be classified into meat with normal colour and in the 24-hour post-mortem evaluation into lighter meat than normal.

The analysed values of $\mathrm{pH}$, water retention capacity (WRC) and shear force (SF) of the breast meat were not influenced $(\mathrm{P}>0.05)$ by $\mathrm{DRC}$ inclusion and carbohydrase addition. Weight loss by cooking (WLC) was influenced $(\mathrm{P}<0.05)$ by inclusion levels of the DRC, presenting a quadratic behaviour, and the inclusion level of the DRC that determined the maximum response value was
$6.51 \%$, which reflected $27.7 \%$ of WLC (Table 9).

Meat quality can be affected by factors related to the animal, nutrition, environmental and sanitary conditions, management techniques and procedures before and after slaughter. Criteria such as colour, $\mathrm{pH}, \mathrm{WRC}, \mathrm{SF}$ and WLC can be used to evaluate meat quality (MENDES; KOMIYAMA, 2011).

The $\mathrm{pH}$ of the meat is considered a determinant factor in the quality of the final product. Likewise, WRC is an important factor because it is associated with the characteristics of the meat before and during cooking and its palatability. This variable can be correlated with $\mathrm{pH}$, and the lower the WRC, the lower the final $\mathrm{pH}$ of the meat as well as the softness of the breast meat (MENDES; KOMIYAMA, 2011).

According to Ramos and Gomide (2007), the texture, which corresponds to SF, is classified in values below $3.62 \mathrm{kgf}$ for extremely tender meats, from 6.62 to $9.60 \mathrm{kgf}$ for slightly soft to slightly hard meat and above $12.60 \mathrm{kgf}$ for extremely hard meats. In this study, the texture of the breast meat can be considered extremely soft, which applies for all levels of DRC inclusion.

The factors brightness $(\mathrm{L})$ and colour a * were not influenced $(\mathrm{P}>0.05)$ by DRC inclusion and carbohydrase addition (Table 10). 


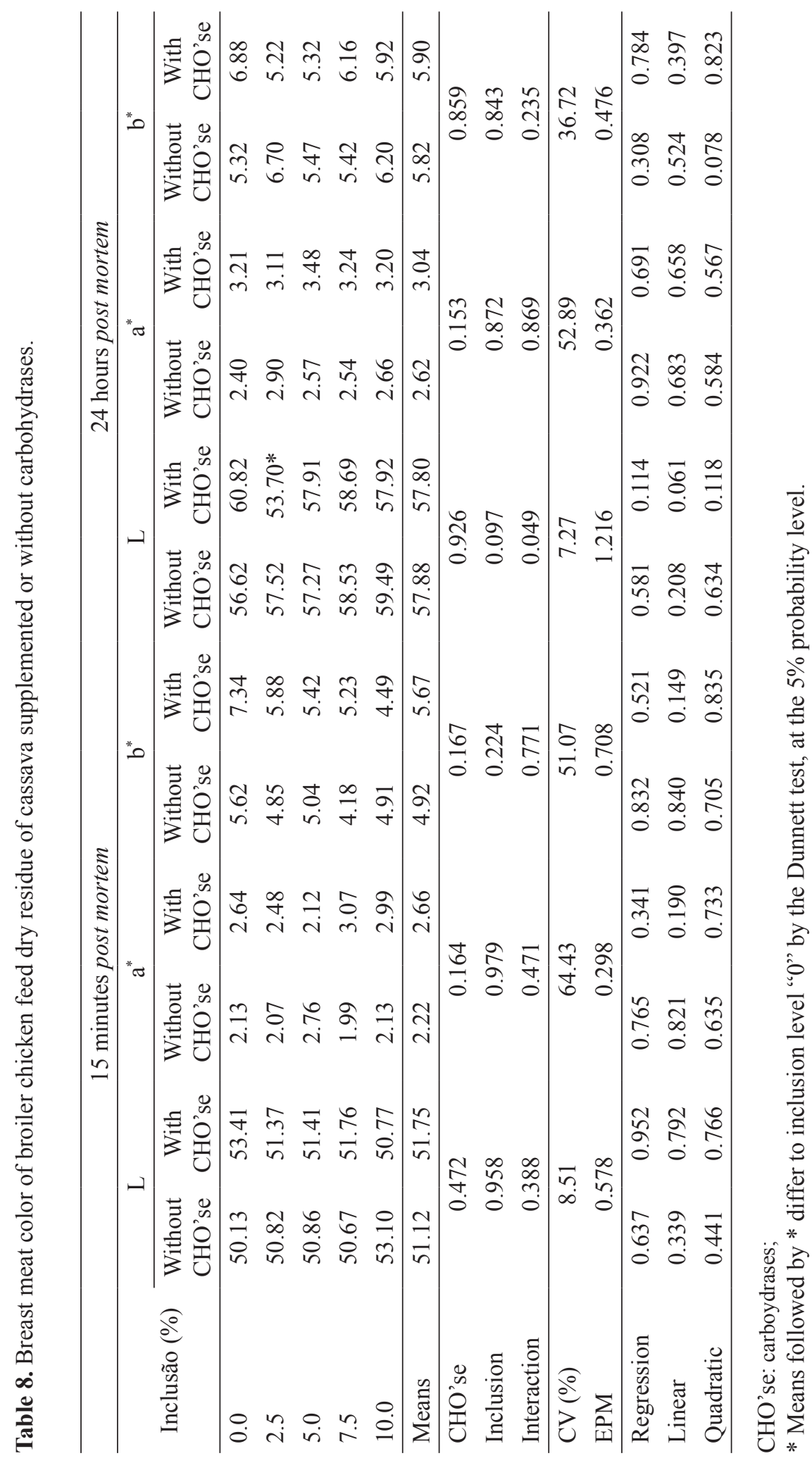


Table 9. Quantitative characteristics of breast meat of broiler chicken feed with dry residue of cassava supplemented or without carbohydrases.

\begin{tabular}{lccccc}
\hline Inclusion (\%) & $\begin{array}{c}\text { pH 15' post mor- } \\
\text { tem }\end{array}$ & $\begin{array}{c}\mathrm{pH} \text { 24h post } \\
\text { mortem }\end{array}$ & $\begin{array}{c}\text { Water retention } \\
\text { capacity (\%) }\end{array}$ & $\begin{array}{c}\text { Weight loss by } \\
\text { cooking (\%) }\end{array}$ & Shear force (kgf) \\
\hline 0.0 & 6.10 & 6.10 & 54.74 & 27.16 & 2.71 \\
2.5 & 6.12 & 5.96 & 58.11 & 23.95 & 3.00 \\
5.0 & 6.16 & 5.93 & 56.82 & 25.88 & 3.25 \\
7.5 & 6.14 & 5.98 & 54.79 & 28.64 & 3.41 \\
10.0 & 6.12 & 5.97 & 53.81 & 24.15 & 2.87 \\
\hline Mean & 6.13 & 5.99 & 55.66 & 25.96 & 3.05 \\
\hline CHO'se & 0.662 & 0.366 & 0.370 & 0.923 & 0.312 \\
Inclusion & 0.912 & 0.154 & 0.104 & 0.004 & 0.265 \\
Interaction & 0.367 & 0.214 & 0.904 & 0.581 & 0.686 \\
\hline CV(\%) & 3.12 & 3.66 & 14.29 & 17.05 & 36.13 \\
EPM & 0.133 & 0.212 & 1.203 & 1.247 & 0.475 \\
\hline Inclusion & 0.915 & 0.289 & 0.105 & 0.004 & 0.411 \\
Linear & 0.997 & 0.505 & 0.064 & 0.448 & 0.836 \\
Quadratic & 0.498 & 0.600 & 0.906 & 0.002 & 0.113 \\
\hline
\end{tabular}

CHO'se: carboydrases;

$\mathrm{WLC}=16.784625+3.34765 \mathrm{DRC}-0.2571 \mathrm{DRC}^{2}\left(\mathrm{R}^{2}=0.77\right)$.

Table 10. Color of the feet of broiler chicken feed with dry residue of cassava supplemented or without carbohydrases.

\begin{tabular}{lccc}
\hline Inclusion (\%) & $\mathrm{L}$ & $\mathrm{a}^{*}$ & $\mathrm{~b}^{*}$ \\
\hline 0.0 & 72.92 & -0.39 & 29.65 \\
2.5 & 71.51 & -0.72 & 27.87 \\
5.0 & 73.49 & -1.30 & $25.48^{*}$ \\
7.5 & 69.74 & -0.06 & $25.67^{*}$ \\
10.0 & 73.11 & -1.12 & $24.55^{*}$ \\
\hline Mean & 72.15 & -0.75 & 26.79 \\
CHO'se & 0.418 & 0.216 & 0.940 \\
Inclusion & 0.426 & 0.060 & 0.016 \\
Interaction & 0.133 & 0.153 & 0.915 \\
\hline CV (\%) & 9.69 & 20.10 & 17.99 \\
EPM & 1.106 & 0.657 & 1.255 \\
\hline Inclusion & 0.364 & 0.407 & 0.241 \\
Linear & - & - & 0.088 \\
Quadratic & - & - & 0.491 \\
\hline
\end{tabular}

CHO'se: carboidrases;

* Means followed by * differ to inclusion level " 0 " by the Dunnett test, at the $5 \%$ probability level. 
The negative values of $\mathrm{a} *$ indicate the tendency of the meat to take on a green color, as opposed to the positive values, which represent a red colour (MINOLTA, 2007). Coloration can vary according to the muscle or organ evaluated and also to the physical activities performed by the animal (FLETCHER, 2002).

The colour variable $\mathrm{b} *$ was not influenced by carbohydrase addition $(\mathrm{P}>0.05)$; however, with the increase of inclusion levels of RSF, there was a decrease of $b *$ values $(\mathrm{P}<0.05)$ from the $5 \%$ level when compared to the control treatment. This indicates a depigmentation in the color of the food and may be related to the lack of pigments in cassava and its co-products (SOUZA et al., 2011).

\section{Conclusion}

Dry residue of cassava can effectively be used in the diet of broilers from 1 to 21 days of age until the evaluated level of $10 \%$, provided that it is associated with the use of carbohydrases, without any damage to the performance or carcass yield and cuts. At slaughter age, meat quality is not negatively impacted. The blood parameters analysed were within the reference values for broiler chickens.

\section{References}

ALONSO-ALVAREZ, C.; FERRER, M.; VELANDO, A. The plasmatic index of body condition in yellow-legged gulls Larus cachinnans: a food-controlled experiment. Ibis, Cordoba, v. 144, n. 1, p. 147-149, 2002.

BARBOSA, N. A. A.; SAKOMURA, N. K.; FERNANDES, J. B. K.; DOURADO, L. R. B. (2008). Enzimas exógenas no desempenho e na digestibilidade ileal de nutrientes em frangos de corte. Pesquisa Agropecuária Brasileira, Brasília, DF, v. 43, n. 6, p.755762.

BARBOZA, W. A.; ROSTAGNO, H. S.; ALBINO, L. F. T.; RODRIGUES, P. B. Níveis de lisina para frangos de corte de 22 a 40 e 42 a 48 dias de idade. Revista Brasileira de Zootecnia, Viçosa, MG, v. 29, n. 4, p. 10911097, 2000.

BEDFORD, M. R.; APAJALAHTI, J. Microbial interactions in the response to exogenous enzyme utilization. Enzymes in farm nutrition. Londres: Cabi international, 2001. p. 406.

CAIRES, C. M.; FAGUNDES, N. S.; FERNANDES, E. A. Enzimas na alimentação de frango de corte. Revista Eletrônica Nutrtime, Viçosa, MG, v. 5, n. 1, p. 491-497, 2008.

CALDERANO, A. A.; GOMES, P. C.; ALBINO, L. F. T. Composição química e energética de alimentos de origem vegetal determinada em aves de diferentes idades. Revista Brasileira de Zootecnia, Viçosa, MG, v. 39, n. 2, p. 320-329, 2010.

CARDOSO, D. M.; MACIEL, M. P.; PASSOS, D. P.; SILVA, F. V.; REIS, S. T.; AIURA, F. S. Efeito do uso de complexo enzimático em rações para frangos de corte. Archivos de Zootecnia, Córdoba, v. 60, n. 232, p. 10531064, 2011.

CONTE, A. J.; TEIXEIRA, A. S.; FIALHO, E. T.; SCHOULTEN, N. A.; BERTECHINI, A. G. Efeito da fitase e xilanase sobre o desempenho e as características ósseas de frangos de corte alimentados com dietas contendo farelo de arroz. Revista Brasileira de Zootecnia, Viçosa, MG, v. 32, n. 5, p. 1147-1156, 2003.

DU, M.; AHN, D. Effect of dietary conjugated linoletic acid on the growth rate of live broilers and on the abdominal fat content and quality of broiler meat. Poultry Science, Champaign, v. 81, n. 3, p. 428-433, 2002.

FERREIRA, A. H. C.; LOPES, J. B.; ABREU, M.; FIGEIRÊDO, A. V.; RIBEIRO, M. N.; SILVA, F. E. S.; MERVA, R. R. Raspa integral da raiz de mandioca para frangas de um a 42 dias de idade. Revista Brasileira de Saúde e Produção Animal, Salvador, v. 13, n. 1, p. 160172, 2012.

FLETCHER, D. L. Poultry meat quality. Worlds Poultry Science, New York, v. 58, n. 2, p. 131-145, 2002.

GONZÁLEZ-ALVARADO, J. M.; JIMENEZMORENO, E.; LAZARO, R.; MATEOS, G. G. Effect of type of cereal, heat processing of the cereal, and inclusion of fiber in the diet on productive performance and digestive traits of broilers. Poultry Science, Champaign, v. 86, n. 8, p. 1705-1715, 2007.

GONZÁlEZ, F. H. D.; SCHEFFER, J. F. S. Perfil sanguíneo: ferramenta de análise clínica, metabólica e nutricional. Avaliação metabólico-nutricional de vacas leiteiras por meio de fluidos corporais (sangue, leite e urina). In: CONGRESSO NACIONAL DE MEDICINA VETERINÁRIA, 29., 2002, Gramado. Anais... Gramado: Editora, 2002. p. 5-17.

GREENE, C. E. Infectious diseases of the dog and cat. Athens: Saunders, 2006. 934 p. 
HONIKEL, K, O. Reference methods for the assessment of physical characteristics of meat. Journal Meat Science, Hyderabad, v. 49, n. 4, p. 447-457, 1998.

LUMEIJ, J.T. Avian clinical biochemistry. IN: KANEKO, J.J.; HARVEY, J.W.; BRUSS, M.L. Clinical Biochemistry of Domestic Animals 5th edition. San Diego, Academic Press, 1997. 932p.

MENDES, A. A.; KOMIYAMA, C. M. Estratégias de manejo de frangos de corte visando qualidade de carcaças e carne. Revista Brasileira de Zootecnia, Viçosa, MG, v. 40, n. 1, p. 352-357, 2011.

MINOLTA, K. Precise color communication. Japan: Editora, AJFIPK, 2007. 59 p. Available at: <http://www. konicaminolta.com/instruments/knowledge/color/pdf/ color_commun ication.pdf $>$. Accessed at: 20 jun. 2015.

MOTTA, V. T. Bioquímica clínica para o laboratório: princípios e interpretações. 4. ed. Porto Alegre: Editora Médica Missau; São Paulo: Robe Editorial, 2003. 419 p

MOURÃO, D. M.; SALES, N. S.; PINHEIRO, H. M. S. Biodisponibilidade de vitaminas lipossolúveis. Revista de Nutrição, Campinas, v. 18, n. 4, p. 529-539, 2005.

NAKAMURA, M.; KATOK, K. Influence of thawing method on several properties of rabbit meat. Bulletin of Ishika Prefecture College of Agriculture, Tokyo, v. 11, n. 1, p. 45-49, 1985.

OLIVO, R.; SOARES, A. L.; IDA, E. I.; SHIMOKOMAKI, M. Dietary vitamin e inhibits poultry PSE and improves meat functional properties, Journal of Food Biochemistry, Malden, v. 25, n. 4, p. 271-283, 2001.

PICOLI, K. P.; MURAKAMI, A. E.; NUNES, R. V.; AMARAL, D. C. R. do; EYNG, C.; OSPINA, R. I. C. Cassava starch factory residues in the diet of slowgrowing broilers. Tropical Animal Health and Production, New York, v. 46, n. 8, p. 1371-1381, 2014.

QIAO, M.; FLETCHER, D. L.; NORTHCUTT, J. K.; SMITH, D. P. The relationship between rawbroiler breast meat colour and composition. Poultry Science, Champaign, v. 81, n. 3, p. 422-427, 2002.

QIAO, M.; FLETCHER, D. L.; SMITH, D. P.; NORTHCUTT, J. K. The effect of broiler breast meat color on $\mathrm{pH}$, moisture, water holding capacity, and emulsification capacity. Poultry Science, Champaign, v. 80, n. 5, p. 676-680, 2001.

RAJMAN, M.; JURÁNI, M.; LAMOSOVA, D.; MACAJOVA, M.; SEDLACKOVA, M.; KOSTAL, L.; JEZOVA, D.; VYBOH, P. The effects of feed restriction on plasma biochemistry in growing meat type chickens (Gallus gallus). Comparative Biochemistry and
Physiology Part A: Molecular \& Integrative Physiology, Amsterdam, v. 145, n. 3, p. 363-371, 2006.

RAMOS, E. M.; GOMIDE, L. A. M. Avaliação da qualidade de carnes: fundamentos e metodologias. Viçosa, MG: Ed. UFV, 2007. 599 p.

RAUPP, D. S.; MOREIRA, S. S.; BANZATTO, D. A.; SGARBIERI, V. C. Composição e propriedades fisiológico-nutritivas de uma farinha rica em fibra insolúvel obtida do resíduo fibroso de fecularia de mandioca. Revista Ciência e Tecnologia de Alimentos, Campinas, v. 19, n. 2. p. 1-9, 1999.

ROMERO, L. F.; PARSONS, C. M.; UTTERBACK, P. L.; PLUMSTEAD, P. W.; RAVINDRAN, V. Comparative effects of dietary carbohydrases without or with protease on the ileal digestibility of energy and amino acids and AME $\mathrm{n}$ in young broilers. Animal Feed Science and Technology, Madrid, v. 181, n. 1, p. 35-44, 2013.

ROSTAGNO, H. S.; ALBINO, L. F. T.; DONZELE, J. L.; GOMES, P. C.; OLIVEIRA, R. F.; LOPES, D. C.; FERREIRA, A. S.; BARRETO, S. L. T.; EUCLIDES, R. F. Tabelas brasileiras para aves e suínos: composição de alimentos e exigências nutricionais. Viçosa, MG: Universidade Federal de Viçosa, 2011. 186 p.

SAKOMURA, N. K.; ROSTAGNO, H. S. Métodos de pesquisa em nutrição de monogástricos. Jaboticabal: Funep, 2007, 283 p.

SARTORI, J. R.; PEREIRA, A. K.; GONÇALVES, C. J.; CRUZ, V. C.; PEZZATO, A. C. Enzimas e simbióticos para frangos de corte criados no sistema convencional e alternativo. Ciência Rural, Santa Maria, v. 37, n. 1, p. 235-240, 2007.

SAVÓN, L. Alimentos altos en fibra para especies monogástricas. Caracterización de la matriz fibrosa y sus efectos en la fisiología digestiva. Revista Cubana de Ciência Agrícola, San José de las Lajas, v. 36, n. 2, p. 91-102, 2002.

SCHMIDT, E.; LOCATELLI-DITTRICH, R.; SANTIN, E.; PAUlillO, A. C. Patologia clínica em aves de produção-uma ferramenta para monitorar a sanidade avícola-Revisäo. Archives of Veterinary Science, Curitiba, v. 12, n. 3, p. 9-20, 2007.

SILVA, T. P. L; CABELLO, C. Propriedades da pasta e concentração de amido resistente em duas variedades de raízes de mandioca em diferentes estágios de desenvolvimento. Revista Energia da Agricultura, Botucatu, v. 25, n. 1, p. 138-151, 2010.

SAEG. Sistema para análises estatísticas. Versão 7.0. UFV. Viçosa, MG: Fundação Arthur Bernardes, 1997.

SOUSA, J. P. L.; RODRIGUES, K. F.; ALBINO, L. F. T.; 
VAZ, R. G. M. V.; DA SILVA, G. F.; SIQUEIRA, J. C.; DA SILVA, M. C. (2014). Bagaço de mandioca com ou sem complexo enzimático em dietas de frangos de corte. Archivos de Zootecnia, Córdoba, v. 63, n. 244, p. 657664, 2014.

SOUZA, K. M. R.; CARRIJO, A. S.; KIEFER, C.; FASCINA, V. B.; FALCO, A. L.; MANVAILER, G. V.; GARCÍA, A. M. L. Farelo de raiz integral de mandioca em dietas de frangos de corte tipo caipira. Arcchivos de Zootecnia, Córdoba, v. 60, n. 231, p. 489-499, 2011.
TORRES, D. M.; TEIXEIRA, A. S.; RODRIGUES, P. B.; BERTECHIN, A. G.; FREITAS, R. T. F.; SANTOS, E. C. Eficiência das enzimas amilase, protease e xilanase sobre o desempenho de frangos de corte. Ciência e Agrotecnologia, Lavras, v. 27, n. 6, p. 1401-1408, 2003.

YU, B. I.; CHUNG, T. K. Effects of multiple-enzyme mixtures on growth performance of broilers fed cornsoybean meal diets. Journal of Applied Poultry Research, Oxford, v. 13, n. 2, p. 178-182, 2004. 